\title{
Ironie, umor și cultură în How to Be a Brit de George Mikes: perspective teoretice ale relevanței
}

\author{
María Angeles Ruiz-Moneva ${ }^{(0 *}$ * \\ Facultatea de Filozofieși Litere, Universitatea din Zaragoza, 12 Calle de Pedro Cerbuna, 50009 Zaragoza, Spania
}

\section{Despre articol}

Istoric:

Primit 5 august 2019

Acceptat 16 septembrie 2019

Publicat 7 noiembrie 2019

Cuvinte-cheie:

pragmatică

retorică

stilistică

\begin{abstract}
Rezumat
Lucrarea de față își propune să analizeze rolul pe care umorul și ironia îl joacă în interpretarea cărții lui George Mikes How to be a Brit. Se va arăta că aceste resurse sînt importante pentru ca cititorul să înțeleagă și să se bucure de sensul pe care autorul intenționează să îl comunice. Mikes a căutat să arate inconsecvențele și incongruențele societății și culturii britanice, prin prisma „străinului”, a celui care nu aparține locului. Ironia și umorul devin resurse stilistice care ghidează cititorul în interpretarea textului. Cadrul aplicat este cel al teoriei relevanței, o abordare pragmatică ce evidențiază procesele de inferență implicate în înțelegerea mesajului. Totuşi, viziunea pe care o atare teorie ar oferi-o asupra culturii a fost adesea neglijată sau greșit înțeleasă.

Prin urmare, această lucrare va căuta să urmărească dacă teoria relevanței în ansamblu şi, în mod concret, propunerile sale referitoare la umor, ironie și cultură pot ajuta cititorul să facă față semnificației operei analizate. Se va arăta că un echilibru adecvat între derivarea inferențială a sensului transmis de emițător, pe care o execută cititorul și libertatea lui de a ajunge la propriile concluzii (care sînt în orice situație restricționate de text) ajută la o mai bună înțelegere și interpretare a textului.
\end{abstract}

\section{Introducere}

În How to Be a Brit ${ }^{1}$ [rom.: Cum săfii britanic], alcătuită din How to Be an Alien [rom. Cum săfii un străin], How to Be Inimitable [rom.: Cum să fii neimitabil] și How to Be Decadent [rom.: Cum să fii decadent], George Mikes înfățișează aspecte ce apar în ochii unor străini ca obiceiuri ciudate ale britanicilor. Prin urmare, How to Be a Brit oferă viziuni extrem de satirice, pline de umor și ironie asupra experiențelor pe care autorul le-a avut ca străin în rîndul britanicilor. Perspectiva autorului ca străin îi permite să reflecteze și să extragă ceea ce consideră că este neadecvat la cunoașterea lumii și în cosmoviziunea britanicilor.

O anumită legătură poate fi stabilită între lucrare, protagonist și Mikes, autorul însuși. În Prefețele cărților și cu ocazia celei de-a douăzeci și patra ediții, autorul vorbește despre întîlnirea pe care a avut-o cu editorul André Deutsch, în 1945, și despre interesul acestuia pentru manuscrisul său. Ideea sa centrală viza problematica lui „a fi străin”, adică a adaptării cuiva, străin fiind, la cosmoviziunea britanicilor. Referința se face la receptarea trilogiei: din cauza ironiei și a umorului autorului, ea a apărut ca „o carte atît de amuzantă” (Prefață, p. 9). Asta, chiar dacă autorul susține că nu a intenționat să o facă umoristică - ceea ce este aproape neverosimil:

\footnotetext{
*Adresă de corespondență: mruiz@unizar.es.

${ }^{1}$ George Mikes, How to Be a Brit. A George Mikes Minibus (Penguin, Harmondsworth, 1986) este o trilogie alcătuită din: How to Be an Alien (1946), How to Be Inimitable (1960) și How to Be Decadent (1977). În Prefață, autorul însuși se referă la cele trei în următorii termeni: "How to Be an Alien a fost un cri de cœur, un strigăt disperat de ajutor (...). La scurtă vreme, am adăugat încă două strigăte la primul: How to Be Inimitable, în 1960, cînd începusem să alunecăm, dar încă aveam un Imperiu și refuzam să recunoaștem multe schimbări; și How to Be Decadent, în 1977” (1986, p. 9). În lucrarea noastră se vor face referiri fie la How to Be a Brit, fie la fiecare carte. Pentru citare se vor folosi ghilimele duble (,”).
} 
Care este nemulțumirea mea atunci? Este că această carte a schimbat complet imaginea pe care obișnuiam să o prețuiesc eu însumi. Aceasta trebuia să fie o carte a sfidării. Înainte de publicarea sa, mă simțeam ca un om care urma să le spună englezilor unde să coboare. Am spus ce gîndesc, indiferent de consecințe; m-am gîndit că sint curajos și deschis și mă așteptam fie să trec neobservat, fie să fac față unei furtuni. Dar nu a venit nicio furtună. Mă așteptam ca englezii să fie pe picior de război împotriva mea, dar m-au bătut pe spate; $\mathrm{m}$-am așteptat ca naţiunea britanică să se revolte, dar tot ce au spus a fost: «destul de amuzant». A fost într-adevăr o dezamăgire amară.

(Prefața ediției a douăzeci și patra, p. 14)

Mikes a fost un autor maghiar, născut la Budapesta în 1912. A făcut un doctorat în Drept. După ce a devenit jurnalist, a fost trimis la Londra în calitate de corespondent, pentru o scurtă perioadă de timp, la sfirșitul anilor treizeci, imediat înainte de Al Doilea Război Mondial. Cu toate acestea, a rămas în Marea Britanie pînă la moartea sa, în 1987. A publicat atît în maghiară cît și în engleză. Unele din celelalte lucrări ale sale sînt, de asemenea, legate de mai multe țări ale lumii și de ce înseamnă să locuiești acolo ca străin, cum ar fi How to Unite Nations (1963), The Land of the Rising Yen (1970) sau Switzerland for Beginners (1978). Cu ocazia împlinirii a șaptezeci de ani, a publicat o autobiografie: How to Be Seventy (1982). Prin urmare, într-un anumit sens, situațiile descrise în lucrările analizate ar fi putut fi legate de propria sa experiență de viață, într-o țară străină unde avea să trăiască o perioadă lungă.

Teoria relevanței (mai ales prin Sperber \& Wilson, 1995; Blakemore, 1992; Wilson \& Sperber, 2004; Carston, 2002a; Clark, 2013) oferă o relatare coerentă a comunicării umane ca proces ostensiv-inferențial, în care receptorul încearcă să recunoască în mod inferențial intenția comunicativă a emițătorului. Neînțelegerile pot apărea ca rezultat al identificării greșite pe care receptorul o face intenției comunicative a emițătorului; sau ca nepotrivire a mediilor cognitive ale celor doi, care, în consecință, nu devin „reciproce” sau „manifestate reciproc”. Dar, în același timp, factorii culturali joacă un rol esențial în lărgirea mediului cognitiv împărtășit de comunicator și receptori ${ }^{2}$. Toate aceste aspecte pot fi manipulate pentru crearea umorului și ironiei și acesta este întocmai cazul în How to Be a Brit.

Umorul și ironia au fost analizate pe larg în cadrul teoriei relevanței: primul, în lucrări ale unor autori precum Jodlowiec (1991), Curcó (1995, 1996, 1997a,b, 1998), Torres Sánchez (1999), Yus (1995-1996, 2003, 2004, 2016a) sau Biegajło (2014); a doua a fost abordată chiar înainte ca teoria să fie expusă mod explicit (Sperber \& Wilson, 1995), de Sperber \& Wilson (1978, 1981) sau Carston (1980, 1981), iar propunerile pentru analiza sa se extind pînă în prezent (Yus, 1997-1998, 2000, 2000-2001, 2009, 2012, 2016b, 2016c; Piskorska, 2016; Wilson, 2006, 2009, 2013). Rolul pe care atît ironia cît și umorul îl joacă în crearea stilului vor fi explorate în cele ce urmează. Respectînd cadrul teoriei relevanței, vom porni de la ideea că stilul și efectele stilistice ghidează receptorul în căutarea relevanței optime.

În How to Be a Brit. A George Mikes Minibus, autorul scrie despre impresiile sale cu privire la englezi după ce va fi trăit mai mulți ani printre aceștia. Inițial se plasează pe el însuși pe poziția unui străin în acea societate, un „extraterestru”, și prin aceasta introduce un element central al perspectivei narative.

În esență, o asemenea perspectivă narativă este caracterizată de distanța pe care emițătorul o stabilește între el și englezi. Acest punct de vedere narativ poate conduce, de asemenea, la resurse precum umorul sau ironia. Chiar și așa, el se identifică progresiv cu britanicii și în cele din urmă devine unul dintre ei. Ca rezultat, ironia sa adoptă inițial perspectiva unui străin, dar apoi țintele iniţiale sînt înfățişate şi afectuos, și critic. Aceasta se reflectă în Envoi, cu care se încheie How to Be Decadent: „Let me say one more thing in conclusion. When I wrote that other little book, thirty years ago, I admired the English enormously but did not like them very much; today I admire them much less but love them much more” [rom.: „Să mai spun un lucru în concluzie. Cînd am scris cealaltă cărticică, acum treizeci de ani, am admirat enorm

\footnotetext{
2̂̂n lucrarea de față, prin cultură înțelegem cel mai înalt sau cel mai general nivel al contextului. După Sperber (1996) sau Sperber \& Claidière (2008), cultura trebuie interpretată ca o proprietate a reprezentărilor și practicilor mentale umane împărtăşite de acei indivizi care sînt membri ai unui anumit grup social sau ai unei anumite comunități.
} 
englezii, dar nu i-am plăcut foarte mult; astăzi îi admir mult mai puțin, dar îi iubesc mult mai mult”] (p. 263). Pare, prin urmare, că How to Be a Brit a lui Mikes poate fi potrivită pentru ceea ce ar putea fi numit interfețe dintre ironie și umor.

În ansamblu, Mikes se amuză de unele din cele mai tipice obiceiuri ale englezilor-ceea ce poate $\mathrm{fi}$ numit „stilul de viață britanic”. Totuşi, rîde de ceea ce el concepe ca fiind un sentiment de unicitate, pe care, în opinia sa, englezii l-ar avea despre ei înșişi.

Ironia și umorul devin aspecte centrale in interpretarea cărții How to Be a Brit. Voi susține, încercînd să demonstrez, că cele două resurse sînt strîns legate în lucrare. Acest lucru se întîmplă pentru că, pe de o parte, autorul își propune să-i ridiculizeze pe britanici, în special ceea ce el consideră trăsături britanice distinctive-dintre care cel puțin unele sînt de fapt împărtășite de majoritatea străinilor; pe de altă parte, o face distanțîndu-se de ținta atacurilor sale, fiind, prin urmare ironic. În lucrare, aceste aspecte vor fi analizate urmînd mai ales o perspectivă teoretică a relevanței. În lucrare aceste aspecte vor fi analizate urmărind mai presus de toate perspectivele teoretice ale relevanței.

\section{Cadrul teoretic}

Legăturile dintre ironie și umor au fost explorate pe scară largă de-a lungul istoriei și discuțiile au ajuns pînă în vremuri foarte recente (Ruiz Gurillo \& Alvarado Ortega, 2013; Attardo, 2001b; Curcó, 1996). Pentru Attardo, ,ironia poate contribui la percepția umorului într-un text” (2001b, p. 122). În plus, atît ironia cît și umorul se pot baza pe o oarecare incongruență sau inadecvare contextuală între o anumită situație și așteptările ridicate în legătură cu aceasta (Attardo, 2000, 2001a). Incongruitatea a fost reinterpretată de Yus (1995-1996, 2003, 2004, 2016a) în termenii teoriei relevanței. Există o ciocnire a posibilelor interpretări: între, pe de o parte, cea care este mai probabilă și favorizată contextual și, pe de altă parte, acea interpretare care este mai puțin probabilă în termeni teoretici ai relevanței, dar care este în cel mai probabil să fie comunicată de către emițător și cea care produce efecte umoristice ${ }^{3}$. Astfel, efortul suplimentar de procesare este satisfăcător pentru receptor, și cu cît este mai satisfăcător, cu atît mai mare este responsabilitatea lui de a obține o astfel de interpretare. În mod similar, Curcó (1995) susține că interpretarea afirmațiilor umoristice se bazează pe o interacțiune între două aspecte: și anume, percepția și manipularea incongruenței și căutarea relevanței.

Attardo (2001b) indică eforturile suplimentare de prelucrare în ceea ce privește ironia și umorul și, prin urmare, deschide calea către explicarea teoretică a relevanței ambelor. De fapt, în sfera de aplicare a teoriei relevanței, Curcó (1996) a susținut că atît ironia, cît și umorul sînt rezonante, chiar dacă sursele ecoului în cele două este diferit. Astfel, ironia implică inferențe negative, poate fi înțeleasă ca o negație indirectă și trimite la ipotezele comunicate explicit. În schimb, umorul se bazează practic pe două sau mai multe scenarii semantice care se opun reciproc, se înlocuiesc unul pe altul și care trimit la ipoteze comunicate implicit. Cele mai de bază tipuri de opoziţie la un prim nivel între scenarii, conform lui Raskin (1985), sînt real vs. ireal, normal vs. anormal și posibil vs. imposibil.

Unele din cele mai importante funcţii ale ironiei sînt următoarele (Rodríguez Rosique, 2013): poate consolida complicitatea între participanții la comunicare-în special, oricînd împărtășesc un context sau un mediu cognitiv la care alți participanți nu au acces; poate fi folosit în discursul argumentativ ca strategie de persuasiune; sau poate intensifica un anumit aspect al criticii. Ultima este, probabil, cea mai importantă funcție îndeplinită de ironie în How to Be a Brit.

În cadrul Teoriei Generale a Umorului Verbal (de acum înainte, TGUV) construcția cognitivă a scenariilor, ca domenii de informații interiorizate și structurate, devine primordială. TGUV indică șase surse de cunoștințe, organizate ierarhic, a căror prezență sau absență în text determină dacă acesta este umoristic sau nu. Aceste resurse de cunoştințe sînt: opoziții scriptice, mecanismul logic (care corespunde etapei de rezoluție în modelele de umor cu rezoluție de incongruitate), situație, țintă, strategie narativă și limbaj.

\footnotetext{
${ }^{3}$ De asemenea, în interiorul cadrului teoriei relevanței, Curcó $(1995,1996,1997 \mathrm{a}, \mathrm{b}, 1998)$ se referă la acestea ca fiind cheia asumării și ținta asumării, cea din urmă fiind deci cea care conduce la efecte umoristice.
} 
Abordarea cognitivă a umorului susținută de TGUV face ca această teorie să fie compatibilă, în opinia noastră, cu o abordare teoretică a relevanței umorului și, de asemenea, a relevanței ironiei.

Attardo (2001a) își propune să generalizeze aplicarea acestor teorii la toate tipurile de text, indiferent de lungimea lor, cum este cazul narațiunilor umoristice, și indiferent de gen. Aplicarea TGuv la textele umoristice mai ample și mai complexe decît gluma prezintă două cazuri diferite, în funcție de cît de diferită ori similară este structura lor faţă de cea a glumei. Contribuțiile abordării pragmatice vizează, în mod crucial, importanța abordării sensului în context. Aceasta înseamnă, de asemenea, luarea în considerare a intenției comunicative a emițătorului și a faptului că acesta lasă anumite aspecte implicite, în mod deliberat. Acestea pot fi strîns legate de umor, sensul acestuia fiind lăsat în seama receptorului pentru a fi dedus. Inferența, implicațiile sau presupunerile devin, așadar, parte a miezului comun al instrumentelor analitice ale umorului.

Primul nivel de analiză a textelor umoristice, propus de Attardo \& Raskin (1991) rămîne valabil, dar extindem cercetarea prin încorporarea unor concepte cum ar fi distincția între poanta finală [engl:: punch line] și inserțiile acide de pe parcurs [engl.: jab lines], și acele noțiuni care explică posibila lor distribuție într-un text, și anume, conexiunile [engl.: strands] și acumulările [engl.: stacks]. Construcțiile umoristice ale unui text pot prezenta o complexitate mai largă decît o glumă. Asemenea texte pot prezenta mai multe inserții acide dispersate în întregul text, ca în cazul disjunctorilor difuzi, cum ar fi umorul și ironia.

Se poate afirma căHow to Be a Brit își atinge relevanța optimă prin indicarea modului în care se metareprezintă britanicii pe ei înșiși și, de asemenea, a modului cum străinul, „extraterestrul” îi metareprezintă pe britanici. După cum a subliniat Wilson (1999), metareprezentarea poate fi de patru tipuri: judecăți despre judecăți; judecăți despre afirmații; afirmații despre judecăți; și afirmații despre afirmații. Această ciocnire a celor două tipuri de metareprezentări implicate, respectiv cele emise de străini sau de către cei din afară, pe e o parte, și de britanici, pe de altă parte, devine baza opoziției scriptice care creează umorul în lucrarea analizată.

Astfel, atît ironia, cît și umorul își întemeiază interpretarea pe context, apelînd la procese inferențiale. Abordarea urmărită în lucrarea de față va lua în considerare următoarele ipoteze: umorul și ironia pot fi utilizate de emițătorii care urmăresc o relevanţă optimă și reprezintă utilizări creative ale limbajului. În acest sens, umorul și ironia pot juca un rol important în crearea stilului în text. În cadrul teoriei relevanței, se presupune că stilul ghidează sau constrînge receptorul în căutarea relevanței (Sperber \& Wilson, 1995; Furlong, 1996; Pilkington, 2000; Wilson, 2011; Clark, 2013, pentru a numi doar cîțiva autori reprezentativi). În ceea ce privește relația dintre ironie și umor în lucrare, afirmația noastră centrală este aceea că în How to Be a Brit atitudinea distant-ironică adoptată de narator consolidează efectele comice care se cer a fi comunicate.

În cadrul teoriei relevanței, umorul a fost abordat de autori precum Jodlowiec (1991), Curcó (1995, 1996, 1997a,b, 1998), Yus (2003, 2016a). În ansamblu, principalele puncte ale teoriei relevanței în legătură cu interpretarea afirmațiilor umoristice pot fi următoarele. În principiu, aceste afirmații nu se îndepărtează de nicio presupusă „literalitate” și nici nu au nevoie de niciun mecanism special de procesare. Pentru a face față afirmațiilor pline de umor și, de asemenea, ironice, receptorii ar trebui să respecte ghidajul comprehensiunii euristice, derivat din prezumția de relevanță optimă (Wilson \& Sperber, 2004), care are următorul cuprins:

\section{RELEVANȚĂ GHIDATĂ DE COMPREHENSIUNE EURISTICĂ}

(a) Urmează calea celui mai mic efort pentru obținerea efectelor cognitive: interpretări ale testelor (e.g. dezambiguizări, rezoluții de referință, implicații etc.) în ordinea accesibilității.

(b) Oprește-te cînd așteptările în privința relevanței sînt satisfăcute.

(Clark, 2013, p. 119)

\footnotetext{
${ }^{4}$ Relevanța optimă apare de fiecare dată cînd un enunț sau orice alt stimul are, în orice interpretare dată, pe de o parte, suficiente efecte contextuale sau cognitive pentru a merita atenția receptorului și, de asemenea, pe de altă parte, nu presupune un efort gratuit de procesare în obținerea unor astfel de efecte.
} 
Asta înseamnă că orice efort suplimentar de procesare solicitat de anumite afirmații, cum ar fi ironia sau umorul, va fi depășit de efectele contextuale și cognitive obţinute de receptor. În plus, în cazul interpretării limbajului figurativ se presupune că receptorul are o cantitate mult mai mare de libertate și responsabilitate în atingerea interpretării pe care emițătorul o are de comunicat. Se întîmplă așa pentru că, în construcțiile în care umorul sau ironia joacă un rol semnificativ, implicațiile transmise prin discurs sînt comunicate cu grade mai mici de forță, sub forma unor implicații slabe (Pilkington, 2000; Blakemore, 1992; Sperber \& Wilson, 1995).

Mai exact, și într-o aplicare a teoriei relevanței pentru interpretarea afirmațiilor umoristice, Curcó (1995) face o distincție între implicațiile de prim-plan și cele de fundal, în funcție de gradul lor implicit de relevanță-și, prin urmare, în funcție de efectele lor contextuale. Aceste două tipuri de implicații pot fi manipulate de dragul creării de efecte umoristice. De fapt, acesta este un aspect cheie în utilizarea umorului și a ironiei în How to Be a Brit.

Curcó se ocupă, de asemenea, de similitudinile procesării umorului și ironiei în teoria relevanței. Astfel, ambele implică transmiterea unei atitudini disociative, care se manifestă prin nevoia receptorului de „a se juca” cu două propoziții contradictorii. Ciocnirea dintre propozițiile conflictuale care sînt prezentate publicului cu diferite grade de focalizare-i.e. ipoteze de fundal vs. de prim-plan—și implicațiile acestui lucru pentru afirmaţiile umoristice reprezintă aspecte temeinic analizate şi elaborate în continuare de Yus (mai ales 1995-1996, 2003, 2004, 2013, 2016a,b,c).

Pentru Yus, în cadrul teoriei generale a relevanței, principiul relevanței permite receptorilor să testeze ipotezele în ordinea accesibilității, precum și să selecteze interpretarea pe care vrea să o comunice emițătorul. Acest principiu este valid și aplicabil pentru orice formă de comunicare ostensiv-inferențială. O implicație suplimentară și esențială este aceea că resurse precum umorul sau ironia nu necesită niciun mecanism special de procesare.

În plus, Yus $(2003,2012,2016 a)$ tratează în profunzime relatarea teoretică a relevanței. În discursurile umoristice, emițătorul, care este umoristul, poate manipula așteptările de relevanță ale receptorului. Astfel, prima interpretare congruentă cu principiul relevanței poate inițial să scurteze interpretarea umoristică. Indiferent dacă receptorului i se cere să investească eforturi suplimentare de prelucrare, în cele din urmă, faptul că el atinge în final interpretarea umoristică vizată de emițător, rămasă pînă în momentul respectiv in plan secund, produce efecte contextuale și cognitive suplimentare. În plus, receptorul va fi selectat interpretarea umoristică exclusiv pe baza propriului său proces interpretativ—fapt ce trezește, probabil, o satisfacție suplimentară, deoarece efectele cognitive depășesc eforturile.

Alt principiu al teoriei generale a relevanței, care se aplică în procesarea umorului, are legătură cu faptul că contextul este considerat o entitate cognitivă aleasă de receptor în funcție de accesibilitatea de care se bucură în contextul prevăzut de emițător. După cum remarcă Yus, „Inevitabilă [...] este o reajustare a extinderilor contextuale ale căutării relevanței operate de receptor și a așteptărilor sale în privința relevanței (efort mental vs. interes cognitiv), atunci cînd sînt detectate strategii umoristice” (2003, p. 1300). Un aspect important introdus de Yus (2003) se referă la faptul că receptorul trebuie să se afle in dispoziția necesară pentru a fi distrat sau amuzat: „Efectele umoristice, cum ar fi plăcerea dată de rezolvarea unei incongruențe, merită acest efort cognitiv suplimentar, mai ales dacă receptorul este gata să se alăture jocului glumei" (2003, p. 1300).

Yus susține apoi că diferitele faze ale procesului interpretativ teoretic de decodificare și inferență cu două relevanțe pot fi exploatate în scopuri umoristice (2003, p. 1304 ff.). Acest lucru se datorează în principal faptului că resurse precum ironia sau umorul nu cer niciun mecanism special de procesare. Fazele parcurse sînt: extragerea unei forme logice; soluționarea ambiguității; asocierea referinței; îmbogățirea (sau umplerea unui gol semantic, care poate fi exploatat umoristic); sau derivația implicațiilor. Acest mecanism va fi aplicat analizei umorului în How to Be a Brit.

Yus (2009; 1995-1996, p. 505) consideră că saturația informațiilor și a indiciilor cognitive sînt aspecte principale în prelucrarea atît a ironiei, cît și a umorului. În cazul ironiei, există un criteriu de incompatibilitate între diferitele surse contextuale care permit receptorului să deducă interpretarea intenționat ironică 
a emițătorului. În procesarea umorului sau a unei afirmații umoristice, receptorul nu urmează vreo cale deosebită. Informația obținută din afirmația emițătorului este procesată într-un anumit context sau mediu cognitiv și va produce efecte cognitive. Ceea ce afirmă emițătorul poate, totuși, include anumite implicaturi care sînt transmise cu grade de forță diferite. După cum notează autorul, ironia poate fi asociată strîns cu umorul. Mai mult, combinația celor două, ironie și umor, poate consolida anumite legături existente între comunicatori, cum ar fi prietenia, tovărășia sau chiar solidaritatea (Gibbs, 2005; Gibbs \& Colston, 2002).

În secțiunile următoare, voi încerca să demonstrez că în How to Be a Brit ironia este încă o resursă la dispoziția umorului: practic, ea stabilește contextul și consolidează efectele contextuale care trebuie comunicate. În lucrare, umorul îi permite scriitorului să puncteze și să satiriseze obiceiurile, obișnuințele, atitudinile, caracteristicile, sentimentele britanicilor; prin urmare, este legat de intenția comunicativă a autorului. Asta, deoarece, în principal, așa cum susține teoria relevanței, ironia și umorul sînt rezonante, astfel încît emițătorul tinde să-și exprime atitudinea-de regulă, disprețuitoare, distantă, critică sau altele asemenea-față de propriile-i afirmații sau față de anumite stări de fapt. Din perspectiva teoriei relevanței, atît în ironie, cît și în umor există anumite incongruențe sau incompatibilități între sursele contextuale accesate de emițător. În consecință, receptorului i se va solicita să urmărească interpretarea pe care o consideră cea mai potrivită. Cu cît crește autonomia și responsabilitatea în derivarea implicațiilor comunicate prin aceste incompatibilități contextuale sau incongruențe, cu atît crește satisfacția receptorului. În plus, se poate spune că în How to Be a Brit relația dintre participanți-pe de o parte, emițătorul; pe de altă parte, britanicul—este caracterizată de ambivalență și transformare în timp.

\section{Analiză: strategii și scopuri în transmiterea ironiei și umorului}

În general, ironia și umorul pot duce la neînțelegeri dacă receptorul nu reușește să înțeleagă intenția comunicativă a emițătorului sau, în alte situații, dacă nu reușește să acceseze mediul cognitiv indicat de acesta. Totuși, în How to Be a Brit neînțelegerile sînt cele care duc la ironie (din cauza atitudinii distante a emițătorului față de ceea ce povestește) și la umor (din cauza situațiilor create, care sînt adesea absurde).

Prin urmare, ideea este să analizăm exploatarea umorului și a ironiei în lucrare și să punem în lumină tipurile de strategii umoristice folosite de Mikes pentru a transmite atitudinea lui distant-ironică faţă de ceea ce percepe sau interpretează ca neînțelegeri. Acestea au adesea un fundament intercultural. Se presupune că cultura, precum și diferențele interculturale sînt o parte a contextului sau a mediului cognitiv. Prin urmare, orice lipsă de acces a unui emițător la contextul imaginat de interlocutorul său poate duce la neînțelegeri.

În carte, atît ironia, cît și umorul devin dispozitive esențiale în crearea stilului. În acest sens, în How to Be a Brit ele tind să se completeze și să se contrabalanseze reciproc. Mikes tinde să rîdă de anumite aspecte ale britanicilor, văzute de un străin care, cu toate acestea, se integrează progresiv în societatea respectivă și, cel puțin într-o oarecare măsură, simte o anumită simpatie pentru membrii săi.

Voi arăta în continuare că există cîteva modalități prin care se poate afirma că How to Be a Brit este rezonant. Analiza se va concentra pe următoarele aspecte: pentru început, vor fi studiate Prefețele, în măsura în care ele dezvăluie atitudinea emițătorului, fapt ce subliniază expresia ironiei şi a umorului în lucrare. Mă voi opri apoi asupra strategiilor umoristice angajate în lucrare și a modalităţilor în care acestea sînt afectate de atitudinile distant-ironice adoptate de emițător. În cele din urmă, voi formula concluziile.

\subsection{Prefețele}

How to Be a Brit este formată din trei părți diferite. Autorul însuși se referă la intenția de a scrie o trilogie, în Prefață și, de asemenea, în Prefața la ediția a douăzeci și patra. Prin urmare, aceste piese devin esențiale pentru a analiza perspectiva sau punctul de vedere al autorului despre ceea ce povestește în cele trei părți.

Prima dintre ele este How to Be an Alien (Mikes, 1946), care, în contrast cu așteptările și reacția cititorilor săi, nu a vizat stîrnirea amuzamentului nimănui, după spusele autorului. Cartea este structurată în 
How to Be a General Alien și How to Be a Particular Alien. După cum notează autorul, textul era conceput pentru a-i divulga impresiile de viață printre ceea ce el considera a fi „oameni ciudați” [engl.: „strange people”] (Prefață, p. 9). Prefața oferă cazuri de umor bazate pe contradicții și pe consecințe care nu urmează logic premisele sau presupunerile implicate. Sînt implicate acolo aspecte cruciale ale incongruenței și se fac referiri la scripturi ce se contrazic unul pe altul, din moment ce propozițiile ce se exclud reciproc au același rezultat: „Study these rules, and imitate the English. There can only be one result: if you don't succeed in imitating them you become ridiculous; if you do, you become even more ridiculous" [rom.: „Studiază aceste reguli și imită engleza. Vei cunoaște același rezultat: dacă nu reușești să le imiți, devii ridicol; dacă o faci, devii și mai ridicol."] (How to Be an Alien, Prefaţă, p. 18).

Important este și faptul că, în referințele sale din prefața la How to Be Inimitable: Coming of Age in England (1960), Mikes oscilează și alternează între ei și noi ca subiect gramatical al frazei în care explică scopul acestei părți: „In these past twenty-one years England has gained me and lost an Empire” (p. 97; s.m.); "After the war it seemed that we would hardly survive the blow of victory; nonetheless today we are nearly as well off as the Germans themselves” (p. 98-99; s.m.). [rom.: „În ultimii douăzeci și unu de ani Anglia m-a cîștigat pe mine și a pierdut un Imperiu” (p. 97); „După război, se părea că cu greu vom supraviețui noi loviturii victoriei; cu toate acestea, astăzi noi sîntem în stare aproape la fel de bună ca și germanii înșiși” (p. 98-99)]. Autorul se adresează direct publicului: „Oh, yes, if you want to be a modern Briton-a Briton of the sixties-you have to follow an entirely a new set of rules. Here they follow" (p. 99; s.m.). [rom.: „O, da, dacă vrei tu să fii un britanic modern—un britanic al anilor șaizeci-tu trebuie să urmezi un set complet de reguli. Iată-le” (p. 99)].

Un aspect neobişnuit al How to Be a Brit (aspect ce trebuie subliniat în legătură cu publicul vizat de autor) are de a face cu faptul că, spre deosebire de ce se spune în tratate-e.g. Muecke $(1969,1970,1982)$ sau Booth (1974) —, nu există o dihotomie clară între publicul care ar putea face faţă ironiei, pe de o parte, și publicul care nu ar reuşi să o facă, pe de altă parte. Este aceasta o trăsătură importantă a ironiei care, în termenii teoretiei relevanței, a fost prezentată ca accesibilitatea contextului de autori precum Yus (19971998, 2000,-, 2009, 2012). Totuși, ceea ce pare să fie valabil în privința publicului sau a potențialei ținte a ironiei în How to Be a Brit este că acesta/aceasta poate fi considerat/ă ca fiind transversal/ă, în sensul că atît publicul britanic, cît și celelalte tipuri de cititori pot avea acces la sensul intenționat de emițător. Într-un anumit sens, acest lucru se poate datora amestecului umorului și ironiei în lucrare.

În ansamblu, Prefețele stabilesc contextul și oferă baza opozițiilor sceneriilor care duc la umor, care vor fi proiectate în restul fiecăreia dintre cele trei părți ale cărţii. De asemenea, prefețele oferă indicii clare despre atitudinea emițătorului și despre intenția comunicativă a acestuia de a se distanța de ceea ce povestește şi de țintele umorului și ironiei.

\subsection{O analiză teoretică a relevanței umorului și ironiei în How to Be a Brit}

Un aspect deosebit de interesant al cărții How to Be a Brit în privința ironiei și a umorului se referă la modalitățile in care același subiect este abordat de-a lungul diferitelor părți care compun trilogia. Acest aspect poate duce la ironie rezonantă și la umor, arătînd modul în care autorul se raportează la același subiect, din primele secvențe ale celorlalte cărți ale sale. În ceea ce privește ironia, referirile acestea pot fi considerate cazuri a ceea ce Hatim (1997) a numit ecouri intertextuale, a cărui sursă o constituie alte lucrări sau texte și care, în opinia mea, nu se aplică numai la traducere. În acest sens, se poate propune o nuanţare sau o distincție suplimentară între sursele intertextuale și ecourile intertextuale. Diferența dintre cele două constă în faptul că sursele intertextuale au legătură cu conexiunile care pot fi găsite între diferite texte, dar care, spre deosebire de ecourile intertextuale, nu trebuie să fie legate de transmiterea ironiei. Aceste surse intertextuale pot fi corelate într-o oarecare măsură cu manifestarea principiului confirmării (sau al consolidării) presupunerilor. În termenii teoriei relevanței, acesta este un proces cognitiv prin care informațiile noi întăresc și oferă dovezi pentru presupuneri vechi. Într-un anumit sens, conceptul lui Hatim de ecouri intertextuale (1997) ar fi un tip specific de surse intertextuale. Ecourile intertextuale se referă la acele manifestări ale ironiei a căror sursă este identificată în alte texte. Următoarele două părți 
ale trilogiei, care urmează secțiunea How to Be an Alien, permit și ele cititorului să înțeleagă cum a fost receptată cartea, lăsîndu-se la o parte faptul că atitudinea autorului este în mod vădit umoristică și ironică.

Astfel, în varii părți ale lucrării, aceste surse și ecouri intertextuale au legătură cu aspecte ale vieții britanice cum ar fi statul la coadă, a (nu) fi deștept, păreri despre limbă, ceai sau cumpărături. Acestea sînt cazurile pe care se va baza analiza.

Pentru început, iată ce remarcă autorul cu privire la statul la coadă, atît în How to Be an Alien, cît și în How to Be Decadent:

(1) An Englishman, even if he is alone, forms an orderly queue of one.

[Un englez, chiar dacă este singur, formează o coadă ordonată de unu.]

(How to Be an Alien: The National Passion, p. 54)

Quite a few people told me that I was mistaken when I made fun of the English queuing habit. It was simply a war-time expediency, it was explained to me, and it would disappear in no time. It is still with us and will remain with us forever because it corresponds to an inner need, it is a way of self-expression. Other nations need occasional outbursts of madness and violence; the English need occasional excesses of self-discipline. Other nations, under unbearable stress, shout, howl, get into brawls, run amok; the English queue up for a cup of tea.

Demonstrations in other countries are violent affairs, with baton charges and mass arrests. Such things have occurred here, too, in the past. Today, if you are bored, you arrange a demo.

[Destul de mulți mi-au spus că m-am înșelat cînd m-am amuzat de obiceiul de a sta la coadă al englezilor. Mi s-a explicat că fusese, pur și simplu, un expedient în timpul războiului și că va dispărea în cel mai scurt timp.

Este în continuare cu noi și va rămîne cu noi pentru totdeauna, deoarece corespunde unei nevoi interioare, este o modalitate de auto-exprimare. Alte națiuni au nevoie de izbucniri ocazionale de nebunie și violență; englezii au nevoie de excese ocazionale de autodisciplină. Alte națiuni, cînd se află sub vreun stres insuportabil, strigă, urlă, intră în lupte, aleargă nebunește; englezii se aşază la coadă pentru o ceașcă de ceai.

Demonstrațiile din alte țări sînt treburi violente, cu asalt la baston și arestări în masă. Asemenea lucruri s-au întîmplat și la noi, în trecut. Astăzi, dacă te plictisești, aranjezi o demo.]

(How to Be Decadent: On the National Passion, p. 223)

Sînt acestea exemple care arată că ironia și umorul din How to Be a Brit se bazează pe exagerări și hiperbole, care preiau acțiuni și obiceiuri cotidiene și le imping pînă la consecințe maxime și absurde. În viziunea mea, pe acest lucru se sprijină incongruențta, din cauza absurdității opozițiilor de scenariu prezentate. Există un element de fundament cultural ce stă la baza acest exemplu (și, de fapt multe alte exemple) de situație umoristică: multe dintre aspectele care sînt prezentate ca idiosincratic englezești sînt, de fapt, situații comune, banale și recurente în multe părți ale lumii. Ipotezele prezentate ca fiind susceptibile de a fi abandonate sînt, totuși, întărite și consolidate. Mai mult decît atît, consecinţele sînt duse la extremul absurd, ca situații puțin probabile. Acestea sînt prezentate în cadrul a ceea ce teoria-relevanței a numit concepte ad-hoc și pe care Yus (2004, 2016a) le-a aplicat în analiza umorului. În exemplul la care ne-am referit anterior, observația este valabilă în ceea ce privește legătura dintre a fi plictisit și a aranja o „demo”acțiuni care nu sînt coocurente în niciun context obișnuit, care nu împărtășesc niciun element comun și nu au nicio conexiune logică.

\footnotetext{
${ }^{5}$ În cadrul teoriei relevanței, conceptele ad-hoc sînt considerate componente ale explicaturii afirmației emițătorului și oferă acces la setul de presupuneri enciclopedice care permit derivarea implicaturilor. Important este că proprietățile asociate conceptului ad-hoc nu ar fi putut fi preluate nici din conceptul codat inițial, nici numai din vehicul; mai degrabă, provin din asocierea amîndurora (Carston, 2002b). După cum a menționat Clark (2013, p. 249), conceptele sînt întotdeauna ajustate și specificate atunci cînd sînt accesate într-un anumit context, astfel încît să permită receptorilor să obțină anumite implicaturi.
} 
Opiniile autorului despre cum să (nu) fii inteligent pot fi considerate cazuri de ironie rezonantă și umor, care apar în două părți diferite ale trilogiei: în How to Be an Alien și How to Be Inimitable. În acest caz, autorul are păreri similare, astfel încît ironia se bazează pe confirmare sau pe abordarea aceluiași tip de țintă, practic cu același tip de atitudine. Prin urmare, ironia nu se construiește aici pe ecouri intertextuale, ci mai degrabă pe surse intertextuale. Recurența se bazează pe ținta ironiei și pe atitudinea emiţătorului faţă de aceasta. Astfel, ironia şi umorul au ca temei opinii și atitudini similare:

(2) In England it is bad manners to be clever, to assert something confidently. It may be your own personal view that two and two make four, but you must not state it in a self-assured way, because this is a democratic country and others may be of a different opinion.

[În Anglia, să fii deștept, să afirmi ceva cu încredere este de o manieră proastă. Poate fi punctul tău de vedere că doi cu doi fac patru, dar nu trebuie să o declari într-un mod sigur, pentru că asta este o țară democratică, și alții pot fi de altă părere.]

(How to Be an Alien: How Not to Be Clever, p. 42)

One thing you must learn in England is that you must never really learn anything. You may hold opinions - as long as you are not too dogmatic about them-but it is just bad form to know something. You may think that two and two make four; you may rather 'suspect it'; but you must not go further than that. Yes and no are about the two rudest words in the language.

[Un lucru pe care trebuie să îl înveți în Anglia este că niciodată nu trebuie să înveți cu adevărat nimic. Poți păstra păreri-atîta timp cît nu ești prea dogmatic în legătură cu ele—dar este de prost gust să știi ceva. Poți crede că doi cu doi fac patru; poți mai degrabă „să bănuiești”; dar nu trebuie să mergi mai departe de atît. Da și nu sînt cam cele mai nepoliticoase cuvinte din limbă.]

(How to Be Inimitable: On Not Knowing Anything, p. 163; s.m.)

În fragmentul de mai sus, preluat din How to Be an Alien, umorul începe cu poanta unei afirmații satirice care contrazice bunul simț și cunoașterea lumii, care poate fi concluzia ad absurdum a aspectelor particulare pe care autorul le-a observat la britanici. Umorul și, de asemenea, ironia sînt, la fel, fundamentate pe atitudinea distanței rezonante adoptate de emițător față de faptele pe care le interpreteaz $\breve{a}$-mai mult decît le prezintă—în legătură cu acest grup de oameni. Într-un anumit sens, el transmite ca fapt sau presupunere faptică ceea ce nu este decît părere a sa personală. Motivele furnizate de autor nu se poate spune că izvorăsc logic din premise sau presupuneri. Incongruența se concentrează, de asemenea, pe contrastul dintre fapte şi opinii.

Acest contrast între fapte și opinii, sau mai degrabă, între cunoștințe sau cogniție și opinii, este reluat în How to Be Inimitable: și aici apare o afirmație absurdă, prezentată însă ca și cum ar fi logică și suficient de comună. Fapt important, exprimarea atitudinii care produce efecte umoristice și ironice se bazează pe termenii teoriei relevanței ca explicaturi de nivel superior. Acestea implică „înglobarea propoziției exprimate într-o descriere de nivel superior" (Carston \& Uchida, 1998, p. 297), care poate transmite, face referire sau descrie, printre alte aspecte, atitudinea propozițională a emiț̆ătorului. Prin urmare, acestea sînt relevante prin aceea că ghidează și constrîng deciziile pe care cititorul trebuie să le ia cu privire la interpretare (Clark, 2013; Blakemore, 1992).

După cum s-a arătat mai sus, percepțiile autorului despre atitudinile britanicilor cu privire la aspecte precum limbajul sau cumpărăturile, de exemplu, sînt de asemenea recurente în unele sau în toate cele trei lucrări din How to Be a Brit. Astfel, în ceea ce privește limbajul, în How to Be an Alien autorul stăruiește asupra impresiilor sale despre vocabularul englezesc sau asupra varietăților de accente utilizate de emițătorii nativi și conotațiile sociale ale acestora:

(3) If you live here long enough you will find out to your greatest amazement that the adjective nice is not the only adjective the language possesses, in spite of the fact that in the first three years you 
do not need to learn or use any other adjectives. You can say that the weather is nice, a restaurant is nice, $\mathrm{Mr}$ Soandso is nice, Mrs Soandso's clothes are nice, you had a nice time, and all this will be very nice.

[Dacă locuiești aici destul de mult, vei constat, spre marea ta uimire, că adjectivul drăguţ nu este singurul adjectiv pe care îl posedă limba, în ciuda faptului că în primii trei ani nu trebuie să înveți sau să folosești niciun alt adjectiv. Poți spune că vremea este drăguță, un restaurant este drăguț, domnul Cutare este $d r a ̆ g u t$, , hainele doamnei Cutare sînt drăguțe, ai avut parte de timp drăguț și toate acestea vor fi foarte drăguțe.]

(How to Be an Alien: The Language, p. 37; s.m.)

Autorul ia în rîs utilizarea excesivă a cuvîntului nice [rom.: drăguț] de către emițătorii englezi nativi, în ciuda largii sale aplicări la cele mai eterogene aspectele ale cotidianului și, pînă la urmă, a desemantizării sale. Întrucît emițătorii nativi îl folosesc atît de des, străinilor li se va recomanda totuşi să îl folosească. De asemenea, Mikes dă peste absurdități remarcabile ale comportamentului, care sînt exploatate și extinse la situații care sînt puțin probabil să apară în viața reală. De exemplu, dezbate conotaţiile sociale ataşate diferitelor accente care pot fi folosite de emițătorii nativi de engleză și ajunge la creionarea unei situații destul de absurde, altminteri foarte amuzantă:

(4) Anyway, this whole language business is not at all easy. After spending eight years in this country, the other day I was told by a very kind lady: 'But why do you complain? You really speak a most excellent accent without the slightest English'.

[Oricum, toată treaba asta cu limba nu e deloc ușoară. După ce am petrecut opt ani în această țară, zilele trecute mi s-a spus de către o doamnă foarte amabilă: «Dar de ce te plîngi? Vorbești cu cel mai excelent accent, fără cea mai mică urmă de engleză.» ]

(How to Be an Alien: The Language, p. 41)

În How to Be Inimitable, autorul reia problema diferitelor accente utilizate de către persoanele care vorbesc engleza și, de data aceasta, insistă asupra propriei experiențe în ceea ce privește cunoașterea limbii engleze, atît înainte, cît şi după venirea în Anglia:

(5) When I was set to England in 1938, I thought I knew English fairly well. In Budapest my English proved quite sufficient. I could get along with it. On arrival in this country, I found that Budapest English was quite different from London English. I should not like to seem biased, but I found Budapest English much better in many ways.

[Cînd m-am stabilit în Anglia, în 1938, am crezut că știu engleza destul de bine. La Budapesta engleza mea se dovedise suficientă. Mă puteam înțelege cu ea. La sosirea în această țară, am descoperit că engleza de la Budapesta era destul de diferită de engleza din Londra. Nu mi-ar plăcea să par părtinitor, dar am găsit engleza din Budapesta mult mai bună în multe privințte.]

(How to Be Inimitable: On Not Knowing English, p. 158; s.m.)

După cum se vede, una dintre principalele surse ale umorului din lucrare are legătură cu concluziile neașteptate pe care autorul le trage. El introduce o poantă la sfîrșitul glumei sau al textului umoristic. Tema limbii se regăsește, de asemenea, și în a treia parte a trilogiei:

(6) If you want to sound truly English, you must learn to speak the language really badly. It will not be difficult, there are many language schools where they teach you exactly that. (If you are unlucky you may choose one of the old-fashioned ones and be taught English as it should be, and not as it is, spoken.) Remember that everything is a 'situation' or a 'problem' nowadays. In the old days a man was travelling, today he is in a travel situation. 
[Dacă vrei să sune a engleză adevărată, trebuie să înveți să vorbești limba într-adevăr prost. Nu va fi dificil, există multe școli de limbi unde te învață exact așa. (Dacă ești ghinionist, poți alege una dintre cele vechi și să fii învățat engleză așa cum trebuie, și nu așa cum este vorbiă). Nu uita că totul este o «situație» sau o «problemă » în zilele noastre. Pe vremuri, un bărbat călătorea, astăzi se află într-o situație de călătorie.]

(How to Be Decadent: Language, p. 197-198)

Autorul impune astfel o distanță între ultimele sale lucrări și cele anterioare, precum și între atitudinile față de limbă în cele două momente. Este destul de neașteptat și plin de umor, pe de o parte, să auzi pe unul care pare să dea sfaturi despre cum trebuie să se vorbească o limbă, în timp ce, pe de altă parte, observațiile sale sînt destul de incongruente și contradictorii: poate suna cineva cu adevărat englez... dar vorbind limba rău? De asemenea, autorul se amuză de utilizarea excesivă a cuvintelor goale [engl. shell-nouns], cum ar fi lucru, problemă sau situație, termeni generici care sînt prea largi și sub-denotativi și totuși sînt folosiți prea des de emițătorii nativi.

Autorul abordează pasiunea națională britanică (adică statul la coadă) în How to Be an Alien, și în How to Be Decadent:

(7) Queueing is the national passion of an otherwise dispassionate race. The English are rather shy about it, and deny that they adore it.

On the Continent, if people are waiting at a bus-stop they loiter around in a seemingly vague fashion. When the bus arrives they make a dash for it; most of them leave by the bus and a lucky minority is taken away by an elegant black ambulance car. An Englishman, even if he is alone, forms an orderly queue of one.

[Statul la coadă este pasiunea naţională a unei rase altminteri lipsite de pasiune. Englezii sînt destul de timizi în acest sens și neagă că adoră asta.

Pe Continent, dacă oamenii așteaptă într-o staţie de autobuz, ei se plimbă în mod aparent vag. Cînd sosește autobuzul, dau năvală; majoritatea pleacă cu autobuzul și o minoritate norocoasă este preluată de o elegantă ambulanță neagră. Un englez, chiar dacă este singur, formează o coadă ordonată de unul.]

(How to Be an Alien: The National Passion, p. 54)

(8) Quite a few people told me that I was mistaken when I made fun of the English queueing habit. It was simply a war-time expediency, it was explained to me, and it would disappear in no time. It is still with us and will remain with us for ever because it corresponds to an inner need, it is a way of self-expression. Other nations need occasional outbursts of madness and violence; the English need occasional excesses of self-discipline. Other nations, under unbearable stress, shout howl, get into brawls, run amok; the English queue for a cup of tea.

[Destul de mulți mi-au spus că m-am înșelat cînd m-am amuzat de obiceiul de a sta la coadă al englezilor. Mi s-a explicat că fusese, pur și simplu, un expedient în timpul războiului și că va dispărea în cel mai scurt timp.

Este în continuare cu noi și va rămîne cu noi pentru totdeauna, deoarece corespunde unei nevoi interioare, este o modalitate de auto-exprimare. Alte naţiuni au nevoie de izbucniri ocazionale de nebunie și violență; englezii au nevoie de excese ocazionale de autodisciplină. Alte națiuni, cînd se află sub vreun stres insuportabil, strigă, urlă, intră în lupte, aleargă nebunește; englezii se aşază la coadă pentru o ceașcă de ceai.]

(How to Be Decadent: On the National Passion, p. 223)

În cele două cărți menționate, statul la coadă apare ca și cum ar fi un obicei autentic britanic sau englez și nu ar trebui să fie găsit în altă parte. Prin urmare, o caracteristică recurentă a celor două pasaje este aceea că ambele se referă la o stare a lucrurilor ipotetică, care este contrazisă de experiența comună a tuturor, 
aproape peste tot. Prin urmare, textul este un ecou al vieții reale: statul la coadă este o necesitate pentru oricine, oriunde, în multe situații comune cotidiene. Autorul supralicitează și duce realitatea la consecințe maxime, absurde sau incongruente, cu rezultate umoristice: „Un englez, chiar dacă este singur, formează o coadă ordonată de unul”.

Perspectiva exagerată, hiperbolică, este reluată în How to Be Decadent. Explicaţia oferită este oarecum absurdă și incongruentă: de ce ar trebui să se asocieze statul la coadă unui „expedient în timpul războiului”? Pe de altă parte, atît statul la coadă, cît și restul acțiunilor la care face referire autorul (strigătul, urlatul, săritul la bătaie etc.) sînt întreprinse probabil de toată lumea (deci nu numai de britanici) în circumstanțe similare.

În schimb, problema cumpărăturilor, de exemplu, poate fi urmărită în alte două părți din How to Be a Brit, și anume în How to Be Inimitable și în How to Be Decadent:

(9) My greatest difficulty in turning myself into a true Britisher was the Art of Shopping. In my silly and primitive Continental way, I believed that the aim of shopping was to buy things; to buy things, moreover, you needed or fancied. Today I know that (a) shopping is a social-as opposed to a commercial - activity and $(b)$ its aim is to help the shopkeeper to get rid of all that junk.

[Cea mai mare dificultate în a mă transforma într-un adevărat britanic a privit arta cumpărăturilor. În modul meu continental prost și primitiv, am crezut că scopul cumpărăturilor era să cumpăr lucruri; mai exact, să cumpăr lucruri de care am nevoie sau care îmi plac. Astăzi știu că $(a)$ cumpărăturile sînt o activitate socială—opusă activității comerciale—și $(b)$ obiectivul cumpărăturilor este de a ajuta comerciantul să scape de tot acel gunoi.]

(How to Be Inimitable: On Shopping, p. 124; italics as in the original)

(10) Few British people go shopping because they need something, still less because they can afford it. Shopping is a social occasion-an opportunity for a chat, an opportunity to display your charm, to show the world that you are on Christian-name terms with the butcher's second-assistant and not just a casual who has dropped in from the street. When your turn comes, the butcher's full attention will be yours.

[Puțini britanici merg la cumpărături pentru că au nevoie de ceva, încă mai puțini pentru că îşi pot permite. Cumpărăturile sînt o ocazie socială—o ocazie pentru o discuție, o ocazie de a-ți afișa farmecul, de a arăta lumii că sînteți la per tu cu asistentul secund al măcelarului și nu doar un neica nimeni de pe stradă. Cînd îți vine rîndul, te vei bucura de atenția maximă a măcelarului.]

(How to Be Decadent: Shopping, p. 210)

Încă o dată, principala sursă de umor și ironie în text are legătură cu ceea ce autorul prezintă ca fiind contrastul autentic între obiceiurile continentale și, respectiv, cele britanice, dar care se pot găsi oriunde în lume. Acest lucru este consolidat prin utilizarea adjectivelor: „mod continental stupid și primitiv”, în How to Be inimitable. În How to Be Decadent, acest aspect este reflectat în special prin trimiterea la diferite acte de discurs și convenții sociale care pot fi specifice actului ieșirii la cumpărături: „o ocazie de a-ți afișa farmecul, de a arăta lumii că sînteți la per tu cu asistentul secund al măcelarului și nu doar un neica nimeni de pe stradă”. Desigur, cu greu ar putea fi cineva de acord că achiziţionarea este o activitate exclusiv socială, după cum pare autorul să susțină în cele două pasaje, chiar dacă cumpărăturile au într-adevăr o componentă socială - dar nicidecum una fundamentală.

Așa cum sa arătat mai sus, unul dintre modurile în care umorul poate fi transmis și justificat (Yus, 2003, 2016a) are legătură cu exploatarea în scopuri umoristice a diferitelor faze implicate în codarea/decodarea și aspectele inferențiale ale comunicării verbale. Astfel de faze sînt următoarele: extragerea unei forme logice; soluționarea ambiguității; asocierea referinței; îmbogățirea (sau umplerea unui gol semantic, care poate fi exploatat umoristic); sau derivația implicaturilor. 


\subsubsection{Extragerea unei forme logice}

O formă logică se referă la proprietățile logice ale unei reprezentări conceptuale. Poate fi fie propozițională, fie non-propozițională. Dacă este propozițională sau semantic completă, poate fi adevărată sau falsă. Dacă este non-propozițională, formele logice corespund schemelor de presupunere. Datorită procesului de dezvoltare sau extragere a unei forme logice, acestea pot fi completate în ipoteze cu drepturi depline, bazate pe probele contextuale disponibile.

(11) If you want to be really and truly British, you must become a hypocrite.

(...)

I had a drink with an English friend of mine in a pub. We were sitting on the high chairs in front of the counter when a flying bomb exploded about a hundred yards away. I was truly and honestly frightened, and when a few seconds later I looked 'around, I could not see my friend anywhere. At last I noticed that he was lying on the floor, flat as a pancake. When be realized that nothing particular had happened in the pub he got up a little embarrassed, flicked the dust off his suit, and turned to me with a superior and sarcastic smile.

'Good Heavens! Were you so frightened that you couldn't move?'

[Dacă vrei să fii cu adevărat britanic, trebuie să devii un ipocrit.

(...)

Am băut cu un prieten englez într-un bar. Stăteam pe scaunele înalte din fața tejghelei, cînd o bombă zburătoare a explodat la aproximativ o sută de metri distanță. Am fost cu adevărat și sincer inspăimîntat și cînd, cîteva secunde mai tîrziu, m-am uitat în jur, nu mi-am putut vedea prietenul nicăieri. În cele din urmă am observat că stătea pe podea, plat ca o clătită. Cînd și-a dat seama că nu s-a întîmplat nimic special în bodegă, s-a ridicat puțin stînjenit, și-a scuturat praful de pe costum și s-a întors către mine cu un zîmbet superior și sarcastic.

«Cerule! Erai atît de înspăimîntat încît nu te-ai putut mișca?»]

(How to Be an Alien: How to Be a Hypocrite, p. 51; s.m.)

În exemplul de mai sus, o concluzie absurdă este trasă de persoana care susține că nu se speriase, deși este evident că fusese atît de înspăimîntată încît se ascunsese. În timp ce naratorul recunoaște că i-a fost întradevăr frică, prietenul său (care probabil era la fel de speriat ca și el) se preface că nu a fost așa și își exprimă propriile sentimente și atitudini. Interpretarea ironică și umoristică este întărită de faptul că întreaga scenă este narată din perspectiva emițătorului, care nu îl împiedică să furnizeze propria interpretare sau să satirizeze comportamentul prietenului său. Lingvistic, se exprimă prin derivarea posibilelor consecințe ale faptului de a fi speriat. Aici, în schimbul comunicativ dintre autor şi prietenul său, propoziția este îmbogățită cu derivarea concluziilor implicate: „Erai atît de speriat încît nu te-ai putea mișca?”.

\subsubsection{Soluționarea ambiguităților sau dezambiguizării}

Soluționarea ambiguităților sau a dezambiguizării este un alt pas inferențial urmat de către receptor atunci cînd face față semnificației pe care emițătorul dorește să o comunice. Aceasta are de-a face atît cu recuperarea explicaturilor unei afirmații cît și cu selectarea formei propoziționale pe care dorește să o comunice emițătorul. În cadrul teoriei relevanței s-a arătat că acesta este un proces ghidat de așteptările de relevanță întreținute de receptor, în baza accesului său la contextul evidențelor disponibile. În How to Be a Brit acest lucru poate fi ilustrat în pasaje precum:

(12) It is so much nicer to ask, when someone speaks of Barbados, Banska Bystrica or Fiji: 'Oh those little islands ... Are they British?'

(They usually are).

[Este mult mai frumos să întrebi, cînd cineva vorbește despre Barbados, Banska Bystrica sau Fiji: $\ll \mathrm{O}$, acele mici insule... Sînt britanice?» 
(De obicei sînt).]

(How to Be an Alien: How Not to Be Clever, p. 44)

Textul îl prezintă pe emițător amuzîndu-se de cosmoviziunea britanicilor. Umorul este întărit prin afirmația modestă din final, care arată clar care este punctul de vedere al emițătorului și, de asemenea, atitudinea interlocutorului acestuia. Ar fi posibil fie un răspuns pozitiv, fie unul negativ și, prin urmare, receptorului i se cere să întrețină două scenarii posibile. În context, doar răspunsul pozitiv este cel care sporește și consolidează anumite presupuneri stereotipice întreținute în general despre britanici. În cele din urmă, răspunsul pozitiv este recuperat în context și face loc efectelor umoristice. Întrebarea formulată este în cele din urmă retorică, deoarece era de așteptat un răspuns pozitiv (cel puțin din punctul de vedere al britanicilor, în conformitate cu presupunerile autorului). Posibila ambiguitate referitoare la faptul că „acele mici insule” erau sau nu britanice este, prin urmare, dezagregată și exprimată.

\subsubsection{Atribuirea referinței}

În cadrul teoriei relevanței, atribuirea referinței este una din subsarcinile implicate în identificarea formei propoziţionale. Funcția sa este de a face posibil ca pronumele și alte expresii deictice să fie legate de entitatea conceptuală la care se referă.

(13) Bargaining is a repulsive habit; compromise is one of the highest human virtues-the difference between the two being that the first is practised on the Continent; the latter in Great Britain.

[Negocierea este un obicei respingător; compromisul este una dintre cele mai înalte virtuți umanediferența dintre cele două fiind că primul este practicat pe continent; iar cel din urmă în Marea Britanie.]

(How to Be an Alien: How to Compromise, p. 48; s.m.)

După cum se ştie, contrastul între britanici şi restul continentului european este tema majoră a trilogiei. $\mathrm{Nu}$ contează că mesajul de bază pare să fie că ceea ce este criticat la britanici ar putea foarte bine să fie criticat la oricare altă națiune: presupusele diferențe dintre britanici și restul lumii sînt augmentate. Aceste contraste sînt exagerate și ajung să genereze adesea umor și ironie. Prin urmare, devine foarte important să se stabilească care este referentul în fiecare caz.

Ceea ce intenționăm aici este să clarificăm la ce se referă următorii termeni: cei doi (care se referă la negociere și la compromis), primul (referindu-se la negociere) și ultimul (asociat cu compromisul). Starea acesta de fapte este exploatată în scopuri umoristice și ironice, din moment ce nu este limpede dacă ar putea exista vreo diferență între cele două, pe de o parte—chiar dacă cineva poate pretinde asta—, și între Marea Britanie și restul Europei, pe de altă parte.

\subsubsection{Imbogățirea sau umplerea unui gol semantic}

În limba naturală, afirmaţiile tind adesea să fie semantic incomple. Depinzînd de contextul avut în vedere de emițător și, mai important, de contextul la care are acces receptorul, acesta din urmă va tinde să îmbogățească forma logică a afirmației și să îi reducă indeterminările. Acest lucru se produce în procesul de căutare a interpretării relevante a afirmației, astfel încît apar efecte contextuale optime fără eforturi de procesare prea ample. Așa cum a menționat Clark (2013, p. 179), în vederea satisfacerii așteptărilor de relevanță, receptorul poate să stabilească conţinutul explicit al unei afirmații chiar și dincolo de nivelul propoziției complete, care poate fi fie adevărat, fie fals:

(14) I heard of a distinguished, pure-minded English publisher who adapted John Steinbeck's novel The Grapes of Wrath, so skilfully that it became a charming little family book on grapes and other fruits, with many illustrations.

[Am auzit de un distins editor englez cu gînduri pure, care a adaptat romanul lui John Steinbeck Fructele mîniei atît de abil încît a devenit o mică și fermecătoare carte de famile despre struguri şi alte fructe, cu multe ilustrații.]

(How to Be an Alien: A Word on Some Publishers, p. 36; s.m.) 
Procesul de îmbogățire poate conduce la efectul plăcutei surprize oferite de presupuneri-presupuneri care pot să nu fi fost anticipate și care, astfel, contribuie la realizarea umorului. Acesta poate fi cazul în exemplul de mai sus, unde titlul cărții lui Steinbeck a fost dezvoltat inteligent și ștrengărește în scopul criticării sarcinilor editoriale pe care și le impun unii editori. Aspectul acesta reprezintă de fapt principalul obiectiv al criticii dezvoltate de autor în termeni ironici şi satirici.

\subsubsection{Derivarea implicaturilor}

În termenii teoriei relevanței, implicaturile sînt definite ca presupuneri comunicate clar, derivate exclusiv prin procese de inferență pragmatică. Implicațiile sînt concluzii care pot fi extrase logic din anumite premise sau presupuneri. În schimb, implicaturile sînt implicații comunicate intenționat (Clark, 2013, p. 216). Există două tipuri de implicații de bază, și anume premise implicate și concluzii implicate. În teoria relevanței se consideră că receptorul trebuie să ajungă la și să obțină astfel de implicații, astfel încît să deducă sensul intenționat de emițător. Acestea pot fi exploatate pentru efecte umoristice, astfel încît concluziile absurde sau cel puțin neașteptate să poată fi derivate din dovezile furnizate. Să ilustrăm cum funcționează asta în How to Be a Brit:

(15) Q: Why don't they [the British] work harder?

A: They just don't like hard work. The Germans have a reputation for hard work, so they like to keep it up. The British find it boring. Then, apart from a tiny and despicable minority, the British dislike the idea of taking part in the rat race. They will give up certain advantages-knowingly and with their eyes open - in order to be able to stick to certain values and a way of life.

[Q: De ce nu muncesc [britanicii] mai din greu?

A: Pur și simplu, nu le place munca grea. Nemții au o reputație pentru munca grea, aşa că le place să fie angrenați în ea. Britanicii consideră asta plictisitor. Apoi, în afară de o minoritate minusculă şi disprețuită, britanicilor nu le place ideea de a participa la întrecerea asta de şobolani. Vor renunța la anumite avantaje-în cunoștință de cauză și cu ochii deschiși-pentru a putea respecta anumite valori și un mod de viață.]

(How to Be Decadent: How to Panic Quietly, p. 237)

Pasajul de mai sus este inserat în capitolul dedicat studiilor efectuate de mass-media străine care, potrivit lui Mikes, ar fi căutat să identifice motivele pentru ceea ce el numește „boala engleză”: lipsa vreunei preocupări, griji, chiar disperări sau angoase din partea britanicilor, în momentul pierderii Imperiului (stare în răspăr față de așteptările analiștilor străini). Prin urmare, „Q” este intervievatorul—un jurnalist care lucrează în orice mass-media străine; iar "A” reflectă perspectiva lui Mikes sau a protagonistului din How to Be a Brit.

În acest fragment, emițătorul urmează un raționament în care sînt prezentate informaţiile de enciclopedie atașate convențional la rubricile moduri de viață: britanic și, respectiv, german. Deși cineva ar putea avea impresia că se evalua stilul german și că pentru el se făceau unele aluzii spre rafinare, britanicii sînt cei vizați, întrucît se arată reticienți în abandonarea obiceiurilor și obișnuințelor lor.

\subsubsection{Ironie și umor rezultate dintr-o contradicție a așteptărilor}

Unele dintre principalele surse de umor în lucrare au legătură cu perspectiva sau punctul de vedere adoptat. Este adesea reflectat ca o perturbare a aşteptărilor, care poate fi exprimată în diferite moduri, cum ar fi construcțiile condiționale a căror împlinire este imposibilă, dar care sînt formulate ca fiind doar improbabile sau puțin probabile. Unele figuri retorice îmbunătățesc și consolidează interpretarea prevăzută, ghidînd astfel cititorul către aceasta și către relevanța acesteia.

În termenii teoriei relevanței, perturbarea așteptărilor care duc la umor este înscrisă în procesarea în două etape a afirmației, urmărind un proces de ajustare paralelă reciprocă (Clark, 2013, p. 144) ${ }^{6}$. In cazul

\footnotetext{
${ }^{6}$ În cadrul teoriei relevanței, procesul de ajustare reciprocă paralelă explică sarcinile întreprinse de receptor atunci cînd încearcă să înțeleagă mesajul comunicat de emițător. Aceste sarcini au legătură cu înțelegerea explicaturilor, a premiselor implicate și, de asemenea, a concluziilor implicate. Aceste procese sînt desfăşurate în paralel.
} 
enunțurilor umoristice, acest proces de ajustare paralelă reciprocă este explicat în următorii termeni: „Dacă afirmația nu satisface aceste așteptări, poate fi activată o căutare a unei interpretări mai relevante (și conotate umoristic), care merită să fie procesată, chiar dacă solicită un efort mental suplimentar" (Yus, 2004, p. 324) ${ }^{7}$. Autorul explică, de asemenea, cum umoriștii tind să controleze care este informația accesibilă sau proeminentă pentru public, astfel încît anumite implicații (umoristice) ale afirmațiilor pot fi de fundal și chiar irelevante în anumite contexte, dar cu siguranță nu și în altele.

Acest lucru poate fi văzut în următorul exemplu:

(16) The British meteorologists forecast the right weather-as it really should be-and then these impertinent little anti-cyclones interfere and mess up everything.

That again proves that if the British kept to themselves and did not mix with foreign things liked Polar and Azores anti-cyclones they would be much better off.

[Meteorologii britanici prognozează vremea corectă-așa cum ar trebui să fie într-adevăr-și atunci acești mici anticicloni impertinenți interferează și încurcă totul.

Asta dovedește din nou că, dacă britanicii ar sta singuri și nu s-ar amesteca cu lucruri străine ca anticiclonii Polar și Azore, ar fi mult mai bine."]

(How to Be an Alien: The Weather, p. 29)

Autorul rîde de britanici şi de felul în care se percep pe ei înșişi sau de felul în care îi privesc pe alții (străinii, inclusiv pe autorul). Dar nu numai atît: cazuri de autoironie sau umor pot fi, de asemenea, urmărite. Putem vedea în acest fel perspectiva autorului (deci, a emițătorului) față de ceea ce narează; iar aceste elemente indicatoare pot apărea sub formă de subînțelesuri, ambiguităţi, contradicții sau chiar absurdităţi. Se întîmplă asta deoarece concluziile obținute nu pot fi derivate în mod logic din ipotezele formulate, situație la care se referă Curcó (1997b, 1998) cînd vorbește despre presupuneri cheie:

(17) I don't quite know what anti-cyclones are, but this is not important; I hate cyclones and I am very anti-cyclone myself.

[Nu prea știu ce sînt anticiclonii, dar acest lucru nu este important; Urăsc ciclonii și eu însumi sint foarte anti-ciclon.]

(How to Be an Alien: The Weather, p. 29)

\section{Concluzii}

How to Be a Brit de George Mike este o lucrare în care ironia și umorul joacă un rol esențial în crearea nu numai a sensului, dar și a stilului. S-a constatat că ele ghidează cititorul în căutarea relevanței: astfel, analiza a arătat că diferitele faze urmărite de cititor în procesul interpretativ au fost exploatate și manipulate de autor pentru crearea umorului și a ironiei. În plus, nici umorul, nici ironia nu reprezintă o îndepărtare substanțială sau calitativă de la interpretarea vreunei afirmații.

Pe de o parte, ironia este legată de sentimentele, intenția și atitudinea emițătorului. Acest lucru se întîmplă pentru că atitudinea lui poate fi caracterizată pentru distanța remarcabilă pe care o adoptă față de ținta criticii sale. Protagonistul din How to Be a Brit se înfățișează pe el însuși ca privitor din afară, ca străin, și adoptă o perspectivă distantă—și uneori de superioritate, sau mai precis, de detașare—față de ţintele criticii sale.

Pe de altă parte, umorul poate fi legat de scopul central al scriitorului, care este acela de a lua în rîs sau de a satiriza acele aspecte ale vieții britanice pe care le-a găsit remarcabile într-un anumit sens. În ansamblu, ironia poate fi văzută ca unealtă a umorului, ca formă de consolidare și transmitere ale scopurilor

\footnotetext{
${ }^{7}$ Afirmații similare au fost prezentate anterior de Jodlowiec (1991).
} 
comunicative ale autorului. Astfel, ironia și umorul sînt complementare și se consolidează reciproc în crearea stilului.

Analiza noastră, bazată pe teoria relevanței în comunicare, a arătat că ironia este în mod esențial rezonantă. Aceasta înseamnă că ironia are două trăsături fundamentale: în primul rînd, exprimă implicit atitudinea emițătorului față de credințele, gîndurile sau ideile reprezentate; iar în al doilea rînd, atitudinea implicată în ecou corespunde disocierii emițătorului de judecățile reverberate. În carte, acest lucru se observă în perpectiva pe care o adoptă protagonistul, care, fiind caracterizat ca „extraterestru”, ca străin, printre oameni necunoscuți, reușește să le demascheze contradicțiile. Indiferent dacă atitudinea lui este de distanţă sau disociere, unele dintre aspectele criticate pot fi aplicate altor popoare, și chiar observatorului însuși; astfel, acesta se identifică treptat cu obiectul sau cuținta criticii sale.

În ceea ce privește umorul, am arătat că în How to Be a Brit acesta se bazează deseori pe contrazicerea sau deturnarea așteptărilor cititorului, fapt care îl conduce pe acesta din urmă la revizuirea interpretării, inițial mai accesibile, dar incorecte. Interpretarea este obținută urmînd procedurile inferențiale aplicabile oricărui tip de discurs. În acest fel, cititorul tinde să selecteze interpretarea care este cea mai accesibilă întrun anumit context. Și totuși, lărgirea sau extinderea unui astfel de context favorizează sau aduce în prim plan o interpretare alternativă, care poate să fi fost inițial obstrucționată sau de fundal; rezultatul acestui proces este umorul. Analiza a arătat că, așa cum a prevăzut Yus (1995-1996, 2003, 2004, 2016a), aceleași strategii inferențiale pe care le aplicăm, de pildă, la muncă, în procesarea vorbirii de zi cu zi, pot fi aplicate la interpretarea discursului umoristic.

În analiza ironiei și a umorului s-au detectat de asemenea trăsături recurente, care pot fi explicate din perspectiva teoriei relevanței. Astfel, analiza noastră oferă dovezi pentru perceperea ironiei și umorului ca utilizări reverberante ale limbajului. În trilogia studiată, emițătorul-despre care se poate spune că reprezintă autorul „real” sau „istoric” Mikes—se distanțează de ținta criticii sale și o face prezentînd o imagine oarecum îndepărtată, detașată despre britanici, care sînt ținta sa principală.

Am arătat că ironia este folosită ca unul dintre vehiculele sau instrumentele care permit autorului să transmită umorul potrivit intenției sale. În general, analiza a arătat că umorul și ironia nu necesită mecanisme sau căi de procesare specifice. Cele două pot fi abordate ca aspecte ale stilului și, astfel, ghidează cititorul în căutarea relevanței. În consecință, interpretarea lor urmează aceleași procese interpretative ca orice altă afirmație. Aceste procese interpretative sînt apoi manipulate pentru crearea ironiei şi umorului. Nici ironia, nici umorul nu sînt, prin urmare, o proprietate a unui anumit text. Mai degrabă, ele reprezintă aspecte ale intenției comunicative a emițătorului, sînt reflectate, de asemenea, și în stilul textului și, astfel, ghidează sau constrîng receptorul în căutarea relevanței și în recuperarea mesajului ce trebuie comunicat. În final, receptorului i se oferă libertatea să interpreteze o bucată de discurs în cheie ironică sau umoristică, sau ambele; tocmai angajarea receptorului în aplicarea mecanismelor interpretative face ironia și umorul să fie mai plăcute.

\section{Bibliografie}

Attardo, S. (2000). Irony as relevant inappropriateness, în „Journal of Pragmatics”, 32 (6), p. 793-826, Crossref.

Attardo, S. (2001a). Humorous Texts: A Semantic and Pragmatic Analysis, Mouton de Gruyter, Berlin, Crossref.

Attardo, S. (2001b). Humor and Irony in Interaction: From Mode Adoption to Failure of Detection, în Anolli, L., Ciceri, R. \& Riva, G. (eds), Say not Say: New perspectives on miscommunication, IOS Press, Amsterdam, p. 165-185.

Attardo, S. (2013). Intentionality and Irony, în Ruiz Gurillo \& Alvarado Ortega (2013), p. 39-57, Crossref.

Attardo, S. \& Raskin, V. (1991). Script theory revis(it)ed: joke similarity and joke representation model, în „Humor”, 4 (3-4), p. 293-347, Crossref.

Biegajło, M. (2014). From which position should I get this joke?! A relevance-driven joke interpretation: Naive optimism, cautious optimism, sophisticated understanding?, în „International Studies in Humour”, 3 (1), p. 2-14, [online].

Blakemore, D. (1992). Understanding Utterances: An Introduction to Pragmatics, Blackwell, Oxford.

Booth, W. (1974). A Rhetoric of Irony, The University of Chicago Press, Chicago / London.

Carston, R. (1980). Approaches to Verbal Irony, MA thesis, University College London.

Carston, R. (1981). Irony and parody and the use-mention distinction, în „Nottingham Linguistic Circular”, 10, p. 24-35.

Carston, R. (2002a). Thoughts and Utterances, Blackwell, Oxford, Crossref. 
Carston, R. (2002b). Metaphor, ad hoc concepts and word meaning - More questions than answers, în „UCL Working Papers in Linguistics", 14, p. 83-105.

Carston, R. \& Uchida, S. (1998). Relevance Theory. Applications and implications, John Benjamins, Amsterdam / Philadelphia, Crossref.

Clark, B. (2013). Relevance Theory, Cambridge University Press, Cambridge, Crossref.

Curcó, C. (1995). Some observations on the pragmatics of humorous interpretations. A relevance-theoretic approach, in „UCL Working Papers in Linguistics", 7, p. 27-47.

Curcó, C. (1996). The implicit expression of attitudes, mutual manifestness and verbal humour, în „UCL Working Papers in Linguistics", 8, p. 89-99.

Curcó, C. (1997a). The Pragmatics of Humorous Interpretations: A Relevance-Theoretic Account, unpublished PhD dissertation, University College London.

Curcó, C. (1997b). Relevance and the manipulation of the incongruous: Some explorations of verbal humour, în Groefsema, M. (ed.), Proceedings of the University of Hertfordshire Relevance Theory Workshop, Peter Thomas and Associates, Chelmford, p. 68-72.

Curcó, C. (1998). Indirect echoes and verbal humour, în Rouchota, V. \& Jucker, A. H. (eds), Current Issues in Relevance Theory, Benjamins, Amsterdam, p. 304-325, Crossref.

Furlong, A. (1996). Relevance Theory and Literary Interpretation, PhD thesis, University of London.

Gibbs, R.W. (2005). Irony as persuasive communication, în Colston, H.L. \& Katz, A.N. (eds), Figurative Language Comprehension. Social and Cultural Influences, L.E.A., Mahwah, p. 131-151.

Gibbs, R. W. \& Colston, H.L. (2002). The risks and rewards of ironic communication, în Anolli, L., Ciceri, R. \& Riva, G. (eds), Say not to Say: New Perspectives on Miscommunication, IOS Press, Amsterdam, p. 181-194.

Hatim, B. (1997). Communication across Cultures. Translation Theory and Contrastive Text Linguistics, University of Exeter Press, Exeter.

Jodlowiec, M. (1991). What makes jokes tick, în „UCL Working Papers in Linguistics”, 3, p. 241-253.

Mikes, G. (1986). How to Be a Brit. A George Mikes Minibus, Penguin, Harmondsworth.

Muecke, D. C. (1969). The Compass of Irony, Methuen, London.

Muecke, D.C. (1970). Irony, Methuen, London.

Muecke, D. C. (1982). Irony and the Ironic, Methuen, London.

Pilkington, A. (2000). Poetic Effects. A relevance theory perspective, John Benjamins, Amsterdam/ Philadelphia, Crossref.

Piskorska, A. (2016). Echo and inadequacy in ironic utterances, în „Journal of Pragmatics”, 101, p. 54-65, Crossref.

Raskin, V. (1985). Semantic Mechanisms of Humor, Reidel, Dordrecht, Crossref.

Rodríguez Rosique, S. (2013). The power of inversion. Irony, from utterance to discourse, în Ruiz Gurillo \& Alvarado Ortega (2013), p. 17-38, Crossref.

Ruiz Gurillo, L. \& Alvarado Ortega, B. (eds) (2013). Irony and Humour. From pragmatics to discourse, John Benjamins, Amsterdam / Philadelphia, Crossref.

Sperber, D. (1996). Explaining Culture. A Naturalistic Approach, Blackwell, Oxford.

Sperber, D. \& Claidière, N. (2008). Defining and explaining culture (comments on Richerson and Boyd, Not by genes alone), în „Biology \& Philosophy”, 23 (2), p. 283-292, Crossref.

Sperber, D. \& Wilson, D. (1978). Les ironies comme mentions, în „Poétique”, 36, p. 399-412.

Sperber, D. \& Wilson, D. (1981). Irony and the use-mention distinction, în Cole, P. (ed.), Radical Pragmatics, Academic Press, New York, p. 295-318.

Sperber, D. \& Wilson, D. (1995 [1986]). Relevance. Communication and Cognition, Wiley-Blackwell, Oxford, $2^{\text {nd }}$ ed.

Torres Sánchez, M.A. (1999). Estudio pragmático del humor verbal, University of Cádiz, Cádiz.

Wilson, D. (1999). Metarepresentation in linguistic communication, în „UCL Working Papers in Linguistics”, 11, p. $127-162$.

Wilson, D. (2006). The pragmatics of verbal irony: Echo or pretence?, în „Lingua”, 116 (10), p. 1722-1743, Crossref.

Wilson, D. (2009). Irony and metarepresentation, în „UCL Working Papers in Linguistics”, 21, p. 183-226.

Wilson, D. (2011). Relevance theory and the interpretation of literary works, în „UCL Working Papers in Linguistics”, 23, p. 6980.

Wilson, D. (2013). Irony comprehension: A developmental perspective, în „Journal of Pragmatics”, 59, part A, p. 40-56, Crossref.

Wilson D. \& Sperber, D. (2004). Relevance Theory, în Horn, L. R. \& Ward, G. (eds), The Handbook of Pragmatics, Blackwell, Oxford, p. 607-632.

Yus, F. (1995-1996). La teoría de la relevancia y la estrategia humorística de la incongruencia-resolución, în „Pragmalingüística”, 3-4, p. 497-508.

Yus, F. (1997-1998). Irony: context accessibility and processing effort, în „Pragmalingüística”, 5-6, p. 391-410, Crossref.

Yus, F. (1999a). Misunderstandings and explicit/ implicit communication, în „Pragmatics”, 9 (4), p. 487-517, Crossref.

Yus, F. (1999b). Towards a pragmatic taxonomy of misunderstandings, în „Revista Canaria de Estudios Ingleses”, 38, p. $217-239$.

Yus, F. (2000). On reaching the intended ironic interpretation, în „International Journal of Communication”, 10 (1-2), p. 27-78.

Yus, F. (2000-2001). Literal/ non-literal and the processing of verbal irony, în „Pragmalingüística”, 8-9, p. 349-374, Crossref.

Yus, F. (2003). Humor and the search for relevance, în „Journal of Pragmatics”, 35 (9), p. 1295-1331, Crossref. 
Yus, F. (2004). Pragmatics of humorous strategies in El club de la comedia, în Márquez-Reiter, R. \& Placencia, M.E. (eds), Current Trends in the Pragmatics of Spanish, Benjamins, Amsterdam, p. 320-344, Crossref.

Yus, F. (2009). Saturación contextual en la comprensión de la ironía, în Ruiz Gurillo, L. \& Padilla García, X. (eds), Dime cómo ironizas y te diré quién eres. Una aproximación pragmática a la ironia, Peter Lang, Frankfurt, p. 309-331.

Yus, F. (2012). Relevance Theory and contextual sources-centred analysis of irony. Current research and compatibility, paper delivered at EPICS V, Pablo de Olavide University (Seville, Spain), March.

Yus, F. (2013). An inference-centered analysis of jokes. The intersecting circles model of bumorous communication, in Ruiz Gurillo \& Alvarado Ortega (2013), p. 59-82, Crossref.

Yus, F. (2016a). Humour and Relevance, John Benjamins, Amsterdam / Philadelphia, Crossref.

Yus, F. (2016b). Relevance theory and contextual sources-centred analysis of irony. Current research and compatibility, în Padilla Cruz, M. (ed.), Relevance Theory: Recent Developments, Current Challenges and Future Directions, John Benjamins, Amsterdam / Philadelphia, p. 147-171, Crossref.

Yus, F. (2016c). Propositional attitude, affective attitude and irony comprehension, în „Pragmatics \& Cognition”, 23 (1), p. $92-$ 116, Crossref.

Yus, F. (2017). Relevance-theoretic treatments of humor, in Attardo, S. (ed.), Routledge Handbook of Language and Humor, Routledge, Abingdon, p. 189-202, Crossref. 